Riin Alatalu, Maris Mändel, Oliver Orro, Triin Reidla

\title{
A CONTROVERSIAL HERITAGE. RESIDENTIAL ARCHITECTURE OF THE TRANSITION PERIOD IN ESTONIA
}

This article looks at residential architecture during the transition period in Estonia from the late 1980s to the early 1990s through the eyes of hertitage experts. It endeavours to sketch the general tendencies and changes in architecture, as well as highlight typical problems in restoration, which arise today in the evaluation of the architectural heritage from that period.

The end of the 1980s and beginning of the 1990s are regarded as a transition period, when Estonia transitioned from a totalitarian state to a democratic nation restoring the pre-II World War Republic of Estonia. The processes during that time affected society as a whole, ushered in important socio-economic changes and also significant cultural changes. Even though culture as a phenomenon is difficult to define, it is generally understood as the common understanding and collection of values shared by a community, and can then be treated as cultural change according to their perceived collective transformation. ${ }^{1}$

The collapse of the Soviet Union and the social and economic processes that were accompanied by cultural changes immediately before and after the collapse also affected homes and home life. The 
desire to differentiate from the strict standardised Soviet models that determined the homes and homelife in an enourmous territory, and to move, as much as the system allowed, in the direction of homes that enabled individuality and self-expression was already clearly apparent in residential architecture of the late 1970s and early 1980s. During perestroika and the early 1990s, this change was explosive. It was aided by the rapid social stratification that was typical of the period. There was a desire among the economically more successful members of society to convincingly demonstrate their wealth through, among other things, a grand home that was unlike any other. This was facilitated by the relaxed control mechanisms, which in the building industry and especially residential building, meant that almost anything was permitted. At the same time, the previously standardised and strictly controlled building sector, was now open to free market economy. Already during the last years of Soviet rule a certain freedom in entrepreurship had been tolerated, and the restoration of the democratic state further encouraged both designing and building as a commercial activities. The past deficit of materials turned into an oversupply. The market was flooded with dozens of virtually unfamiliar modern building materials and this in turn significantly changed the appearance of buildings.

The way that the new architecture that was being built should relate to the existing built environment also had to be reassessed. On the one hand, the enthusiasm for new opportunities and new materials caused architects and their clients to become confident and eager to create something completely different to what had been done before. This was supported by the easing of existing restrictive norms and regulatory mechanisms, and included the partial collapse of heritage protection, which during the late socialist period had developed into a large-scale well-functioning system that had difficulty adjusting to the new situation. On the other hand, the end of the 1980s and early 1990s in the Baltic States was a boom period regarding their own distinct memory and history. It was suddenly possible to freely look at history and this brought about a general appreciation for historical urban spaces and social criticism of urban planning that neglected traditional building practices, including housing. This opposing tension gave birth to a relatively diverse and even contradictory housing landscape, and clearly reflects social processes taking place in society at that time. Therefore, it could be expected that residential architecture of that time would now clearly be perceived as having cultural value, but assessing its value just 20 to 30 years later is complicated, for both heritage experts and the general public.

Who are heritage experts and what is their point of view? During the last decade the critical heritage studies that became popular usually managed to create strong opposition between the owner/ occupants and heritage experts, accusing the latter of monopolising the definition of heritage sites (a telling example of this is the term AHD - authorised heritage discourse brought into use by Laurajane Smith in 2006), and emphasised that the heritage site is not so much connected with the past as born in the present and based on the viewer's experience and emotions. Critical heritage studies and the extent to which they focus on how different groups understand heritage, look at heritage primarily with methods taken from social science and suggest that this is the only way to approach heritage and thereby deny the need to have a knowledge of history. ${ }^{2}$ The authors of this article rely on their training and work experience and represent the much criticized heritage experts. We believe that knowing the history of a heritage site continues to be important in understanding its value, and recognise that alongside this approach there are also sociological methods that can contribute to heritage evaluation.

Residential architecture in the 1990s is in many ways - through its newness as heritage and unique character - somewhat different to previous heritage objects 'monopolised by heritage protection'. It is still unestablished as a type of heritage, making it possible to use the usual methods of heritage protection assessment, as well as value assessing methods that involve society more broadly than usual. The aim of this article is not however to study 1990s residential architecture from the point of view of critical heritage research nor to determine suitable methods for doing so, but an attempt to provide an initial framework based on information from architecture history and building history in regard to specific buildings and highlight potential problems, which could arise from the implementation of

2 Jeremy C. Wells, "Bridging the Gap between Built Heritage Conservation and Critical Heritage Studies", Human-Centered Built Environment Heritage Preservation. Theory and Evidence-Based Practice, ed. by Jeremy C. Wells, Barry L. Stiefel (New York: Routledge 2018), 33-41. 
the traditional discourse regarding heritage, and thereby creating a need for alternative approaches in the discussion.

Even though relatively few homes were built during the transition period compared with the previous and following decades, it is nonetheless an exciting period and a largely unresearched field in Estonian architecture history. ${ }^{3}$ Understanding and assessing the value of homes built during that period has been a considerable challenge for heritage experts. The period is also exciting as the 'preparatory period' before the construction boom of the 2000s. Discussion about the evaluation of the transition period in residential architecture is timely because with the new heritage protection regulations that came into effect in May 2019 the National Heritage Board has started to map evaluations of buildings in the historical towns, as have local municipal councils in significant milieu protection areas. Until now all buildings built since 1991 were marked in inventories as 'new building'. Years later it is now worth considering furnishing this term with a value assessment - this will not be easy. Unlike buildings that were built in the 1990s as part of a complex of buildings, those in historical areas are still like foreign bodies and an adequate assessment of their value is affected by personal emotions and 'old grudges' that regard these as buildings polluting the historical urban environment.

In this article residential architecture of the transition period is viewed using the 'onion' method at three different levels - focusing on the building's basic elements - the materials, at the level of individual buildings and in the more general context of the urban space. Analysis of the buildings and materials highlights the typical problems of assessing transition period residential architecture, whereas looking at it from the viewpoint of the urban space demonstrates the opposing affect of new and historical buildings within that space. The triumph of the market economy and private ownership influenced heritage protection in the historical urban space and visa versa - the new aims of heritage protection and insitutional change affected the building market, as well as the resulting architectural solutions. The first half of the article focuses on residential architecture of the transition period and analyses the changes, treating it as a potential heritage

3 In recent years the 1990s have admittedly increased as an area of focus e.g. the planned research project for 2020-2024 "Patterns of Development in Estonian Culture of the Transition Period (1986-1998)". object and asks critical questions about its appreciation and value. The second half of the article, however, on the basis of the historical urban space, looks at how the heritage protection system has influenced 1990s architecture and how the houses that were built influenced the system. This pretends to be an impartial study, which better helps us to understand why the heritage protection system operates the way it does, and at the same time opens up further discussion about possible and necessary changes to the system.

\section{NEW WINDS, NEW MATERIALS, NEW PROBLEMS}

The restoration of $20^{\text {th }}$ century architecture in many ways differs from the way that heritage sites from previous centuries are treated. A large part of the differences is based in one way or another on the materials used in the architecture and the altered relationship between the building material and the architectural concept. Massproduced materials no longer bear the 'mark of the maker' and in the case of buildings built from these materials the authenticity of the building is no longer automatically commensurate with the materials used. It may even be the opposite and the architectural concept may in fact be more important than the preservation of the original material; that is, the appearance of the building, not the materials used. ${ }^{4}$ The $20^{\text {th }}$ century has seen the introduction of thousands of new building materials, setting restorers new and completely different challenges. While building materials and techniques in the first half of the century in Estonia were largely still based on handcrafting, and construction during the Soviet period was typified by statewide planning and a limited range of materials, then it was the 1990s, with its abundance of materials that a whole new palette of problems connected with building materials emerges, such as technical restoration issues based on the newness of the materials, as well as their value and assessment generally.

Before explaining the restoration problems relating to the material side of architecture so we can better understand the situation, it is necessary to talk about the context regarding building at that time. Re-independence was a critical period in many aspects of life, and over the course of a few years the switch from a planned economy

4 Theodore H. M. Prudon, Preservation of Modern Architecture (Hoboken: Wiley, 2008), 44 
to a market economy brought about radical changes and a complete reorientation in the building industry. During the Soviet period, planning, designing and building was mainly concentrated in stateowned design and construction firms. The building of single-family homes was an exception to this and took place outside the system. The preferred buildings were standard design buildings that could be constructed from elements that could be assembled. Reinforced and aerated concrete that could be prefabricated were the preferred building materials and silicate brick wall constructions were also fairly widespread. The use of metal in buildings was however limited Metal constructions were possible in only a few special one-off designs, elsewhere the buildings had to be built using standard reinforced concrete components, even though a metal construction may have been more economical. The use of metal in building was extremely rare because in the USSR metal was intended for the war industry. Designers had to work with a limited selection from product catalogues (e.g. catalogues of reinforced concrete and aerated concrete products), which presented the available standard components. ${ }^{5}$ In addition to the limited selection, the construction market was also haunted by shortages. An individual builder, outside the system, was especially affected by the unavailability of materials and had to be extremely inventive to access the necessary building materials In theory the owner builder should have been able to buy building materials from shops that belonged to the ETKVL ${ }^{6}$ system, but unfortunately only a portion of what had been ordered ended up in the shops. Accessibility varied from material to material. In 1989, for example, $77.8 \%$ of orders for asbestos cement sheets were fulfilled, whereas only $38.6 \%$ of orders for reinforced concrete and only $20 \%$ of order for furnace tiles. ${ }^{7}$ The individual builder simply did not fit into the centralised Soviet system where preference was given to the larger organisations and other construction firms.

5 Architect Jüri Karu and engineers Leo Lipre and Hillar Tassa's recollections in the book Eesti Tööstusprojektist Sweco Projektini. 1944-2007. Projektid, inimesed, sündmused, ed. By Ants Jakobson (Tallinn: Aade, 2016), 166, 179, 182.

6 ETKVL - Eesti Tarbijate Kooperatiivide Vabariiklik Liit (Estonian State Association of Consumer Cooperatives).

7 Lia Gailan, "Eramu- ja taluehitusest. Elamuehituse olukord Eestis seisuga 01.01.1990", Ehitus ja Arhitektuur, 1 (1990), 22-26.
The end of the decade was accompanied by a radical change. The large state organisations collapsed and in their place hundreds of new design and construction firms, based on private capital, were born and they catered directly to the client's needs and wishes. The quantity of available materials increased considerably and materials that were widely used in the rest of the world but which were new in Estonia came onto the market, such as metal cladding panels, metal roofing sheets, plastic windows, PVC floor coverings and paintable textured wallpaper. Availability was no longer determined by restrictions to certain members of society, but by money, which the average citizen in newly re-independent Estonia tended to have a shortage of. It was not easy, even for designers and architects who had been trained within the Soviet system to orientate in the colourful new world of materials, and work tended to be intuitive, and therefore the price paid was time and quality. ${ }^{8}$ A popular new term was 'euro-renovation', which in the beginning referred to the use of contemporary materials, and therefore was highly desirable in interior decoration - typically involving plasterboard walls and floors covered with laminate parquetry.

Once highly regarded, 'euro-renovation' has for many years been a term of derision in heritage protection and the wider property development circles. ${ }^{9}$ So how should we assess and value the material aspect of the architectural heritage of the 1990s? Should we view plasterboard and plastic windows as elements that carry an essence typical of the times and an original material worthy of preservation, or is it instead a secondary aspect of the overall architectural composition, and as such does not have any value in its own right and can be replaced by some other material?

Many materials typical from the 1990s are of a kind that heritage protection has mostly disapproved of when used in historical buildings, and having an appreciation for these is therefore particularly tricky. Plastic windows are a good example. Estonian's first brief acquaintance with these new options in the world of windows already took place at the end of the 1980s. In 1989, there was an exhibition-symposium in Tallinn where the large international

8 Krista Kodres, "Interjöörist tänases Eesti vabariigis", Maja, 1 (1994), 12.

9 Ruth Mägi, "Möödunud aegade õudus - lepime kokku, et euroremont ei tule enam kunag tagasi", https://moodnekodu.delfi.ee/news/ehitus/moodunud-aegade-oudus-lepime-kokku-eteuroremont-ei-tule-enam-kunagi-tagasi?id=81690225 [accessed on 15.03.2020] 
plastic window producer Kömmerling presented their products. The legendary restoration architect Teddy Böckler was so impressed by what he saw that he proposed the use of Kömmerling plastic windows for the eastern wall of the Pühavaimu medieval church complex, restoration completed in 1990, in Tallinn's Old Town..$^{10}$ By the middle of the decade the use of plastic windows in heritage circles had become such an unwelcome thing according to Hain Toss, the chief inspector of the National Heritage Board, writing in an article in 1994 about the use of contemporary and imitative materials in historical buildings. ${ }^{11}$ Today, the official brochure from the National Heritage Board lists the reasons for preferring wooden windows to plastic. ${ }^{12}$ Imagine (a fairly realistic proposition) that in the near future a building with plastic windows from the 1990s might be recognised as a cultural memorial. If the owner wishes to swap the original plastic windows for timber framed windows, should this be permitted? Can today's heritage protection manage to reverse the current firmly held belief and demand that plastic windows, perceived as worthless, be preserved? And let's take this thought one step further and ask whether the plastic windows used in the 1990s on a historical building should be seen as part of restoration history, which does not need to be remedied and can remain?

Evaluation is also connected with the problems associated with ageing materials. In addition to the fact that there is relatively little knowledge about the way that new materials age - no restorer in Estonia had yet been faced with the issue of restoring laminate parquetry or plastic windows - their ageing is encoded with a conflict of values. We are accustomed to seeing modern materials in their new state and do not necessarily accept their signs of ageing. ${ }^{13}$ Where a crackleware effect or worn timber window might provide subject matter for a romantic photograph, then a yellowed and dirty plastic window does not arouse any positive feelings. Using the terminology

10 Archives of the heritage protection unit of Tallinn [Tallinna linnavalitsuse muinsuskaitse osakonna arhiiv], Teddy Böckler, Pühavaimu idaseina taashoonestamise projekt (Tallinn, 1990), 25.

11 Hain Toss, "Uuele elule", Maja, 2 (1994), 11.

12 Muinsuskaisteamet, "Hea aken. Miks eelistada puitakent plastaknale", comp. by Mari Loit, https://www.muinsuskaitseamet.ee/et/hea-aken-miks-eelistada-puitakent-plastikaknale [accessed on 15.03.2020].

13 Prudon, Preservation of Modern Architecture, 25-26. of Alois Riegl, one might say that with modern materials we tend to primarily value their newness.

One typical problem that accompanies the restoration of modern building materials is the difficulty of finding substitute materials. Traditional materials are, however, relatively easy to reproduce; for example, it is possible to mix lime mortar using old recipes and it is possible to produce, in a factory, ceramic bricks of the desired shape and size using handcrafted techniques, as was done, for example, in the restoration of Jaani Church in Tartu. With modern materials there is the danger that production of the required material has ceased and since the production technology for new materials is both complicated and industrially based, it is not possible to find a substitute material. This problem affects finishing and cladding materials in particular, where the available choice is influenced by fashion and quickly changes, and which due to the fact that it is visible, is an important message bearer regarding the character of the period and is possibly more important than the construction material, which becomes secondary.

\section{INDIVIDUAL HOUSES AND APARTMENT BUILDINGS \\ DURING THE TRANSITION PERIOD - CONFLICTING POSTMODERNIST HERITAGE BORN DURING THE WINDS OF CHANGE}

From the 1960s, when large prefabricated apartment blocks were being built, the construction of individual houses in the larger cities decreased greatly because new plots for single houses were not being allocated. In the 1980s, this situation eased to an extent and then expanded greatly during the 1990s, when many people were finally able to achieve the dream of having their own house. These decades were dominated by a postmodernist architectural aesthetic, and it was via foreign theoretical writings that local architects were ignited. Architectural elements of a playful nature, ty pical of postmodernism, were developed - an abundance of shapes, curved floor plans that avoided ninety-degree angles, unusually shaped windows, asymmetrical facade solutions, greenhouses integrated into the house, and much more. In single-family homes these elements, typical of the style, were applied to a lesser or greater degree depending on the architect's individual style. 
Individual houses at the end of the 1980s clearly demonstrate what took place alongside the centralised system of building during the Soviet period and in what way the change of regime affected the building of residential homes. In the 1980s, owners had to build their own homes as before, defying the shortages and difficulties caused by their status outside the system. Contacts were useful, and barter and building in working bees was common. In a way this was also a filter for skill levels - there were empty plots and half completed houses that found new owners. These factors made houses more 'everyday' - plans were followed to greater or lesser degrees, ownerbuilder modifications were common and the building process was often longer than planned. For example, these changes occurred to a greater and lesser extent on Rehe st. in Viljandi, in the 'Architects' suburb in Tartu and in the suburb of Ihaste, planned in the 1980s.

Later, with re-independence, it was no longer necessary for people to build their own homes and it was possible to employ a builder, but because of the confusion and poverty at the beginning of the decade this was nonetheless not an option for a large number of people. Halfcompleted houses from the Soviet period were now finished and the original plans were realised more modestly. For example, a section of the network of streets in Ilmandu was established and houses were built on roughly half the plots. In the middle of the decade, the economic situation began to stabilise and building work began afresh and increasingly more people could afford to build their own home. The new era brought with it new desirable lifestyles - the period of private villas by the sea began, one fine example of this is Kelvingi village near Tallinn, planned in 1994.

Though it would seem that there were many differences between homes of the Soviet period and those of re-independence, they are nonetheless connected by an architectural language and its development. For example, the second half of the 1980s saw the triumph of the open plan kitchen-living room, which is still a common feature of floor plans today. The homes that were built also demonstrate changes in post-modernism over a period of 15 years (1980-1995). By the mid 1990s, most architects had changed direction, since there were new exemplars and tastes had changed, and consequently post-modernism turned into something else. However, there are still those who like the aesthetics of the 1980s.
Critical analysis of the changed aesthetic will probably be future research work for art historians.

In regard to apartment buildings, the most interesting aspect is a weariness with standard designs at the end of the 1980s, and the desire to bypass this at any cost. In addition to historical residential buildings taken under protection, where the use of designs divergent from standard designs was justified by the need to blend in with the valuable environment, this can also be seen elsewhere. It was now also easier to gain permission to build one-off designs and alongside the use of prefabricated concrete details, traditional construction and cladding materials came increasingly back into use. In Lasnamägi, Tallinn's largest area of prefabricated apartment blocks, red brick buildings, mainly in the quarter built for Dvigatel workers, stand out. These also had large windowed studio apartments for artists on the top floors. Red brick buildings, together with the sculptural architectonic gates threaded between them, are typical of the suburb built in the 1980s in the industrial city of Sillamäe (the 'red promenade' or micro-region No. 1). A distinctive and early example of architecture that aimed to communicate with the existing built surroundings and also differentiate itself from the stereotypes of Soviet modernism is Veljo Kaasik's design at 8a Jaama st. in Haapsalu (completed 1984). ${ }^{14}$ At the time, it was considered a very sensitive building, with its stairwells extending up from the remainder of the roofline and the intentionally awkwardly proportioned extensions supposedly reminiscent of dormer windows in the nearby working class suburb, but today it appears merely oversized and brutal.

In Mustamägi, the modernist suburb established in the 1960s, Erki Valdre and Emil Urbel's apartment building at 253-257 Sõpruse avenue (completed 1991), with its powerful silicate brick bulk and ground floor commercial spaces, is positioned between the existing prefabricated apartment buildings. It endeavoured to re-establish a perimetrical street plan in an existing free-form planned suburb, but at the same time, its post-modernism aimed not to oppose but be accepting of the surrounding apartment buildings that all followed standard designs. ${ }^{15}$ As in many other buildings of that time, this building faddishly had apartments that extended through two storeys.

14 Mart Kalm, Eesti 20. sajandi arhitektuur (Tallinn: Prisma Prindi Kirjastus, 2001), 406. 15 Ibidem, 423 
In Valga, where the area under heritage protection was not established until 1995, an apartment building at 3a J. Kuperjanov st. (architect Anne Kose) was built between 1986 and 1991 that boldly sought dialogue with the local jugendstil apartment buildings from the town's building boom at the beginning of the $20^{\text {th }}$ century. ${ }^{16}$ Many apartment buildings paid homage to the architecture of Estonia's first period of independence between the wars, with the use of pebbledash finishes, for example, and curved corner solutions that also made reference to the 1930s, such as the building at 33 Gonsiori st. (AvoHimm Looveer, 1984-1990). ${ }^{17}$ Not one of these apartment buildings or single-family homes from that time are currently under heritage protection. Some of the aforementioned have, however, been listed in the inventory of $20^{\text {th }}$ century architecture. ${ }^{18}$ In addition to the fact that they have not been recognised as heritage sites, there is also the problem, common for many buildings of that period, of the poor quality of the construction and especially the building materials, particularly in the case of red brick facades. Furthermore, one of the most common features of these one-off designs, that aimed to differentiate from the usual residential architecture, was their innovative and unusual floor plans, but these are very difficult to protect with traditional heritage protection methods.

\section{HOW TO EVALUATE POST-MODERNIST HOMES OF THE TRANSITION PERIOD?}

Heritage protection recognises value on the basis of its field of expertise, but it is also important to communicate with the wider public at whose instigation and influence society's assessment of the built heritage from various periods is characterised, and to discover what the problem areas are in the assessment of one or another type of building or architectural period and to which heritage professionals should focus more of their attention? Heritage protection today considers it important and self-evident to include communities in the process of heritage protection.

16 Oleg Kotsenovski, "Valga”, Eesti arhitektuur IV, 115

17 Kalm, Eesti 20. sajandi arhitektuur, 406.

18 Eesti 20. sajandi väartusliku arhitektuuri kaardistamine ja analüüs (Tallinn: Eesti Kunstiakadeemia, 2012), https://register.muinas.ee/public.php?menuID=architecture [accessed on 18.03.2002].
The greater the number of concerned parties involved in the shaping of values, the clearer the commonly understood criteria, and an understanding of the importance of specific buildings is developed..$^{19}$ Until now, the value of the residential architecture of the transition period has not been a topic of discourse among heritage experts, not to mention the wider public. One of the first attempts to analyse the issue of value in regard to this period can be found in the recent master's thesis by Triin Reidla, ${ }^{20}$ in which both heritage experts and 'ordinary people' are questioned and many problem areas become apparent. These undoubtedly most acutely typify single-family homes of that era, but are also applicable to apartment buildings.

One of the main reasons why the assessment of transition period architecture is difficult is undoubtedly the short amount of time since that period. This is illustrated in the assessment given by one of the heritage experts, A house with towers in the style of the 'Village of Fools' is just too crazy. Maybe once upon-a-time it was camp and cool, but now I just cannot see the value in it. ${ }^{21}$ It is partly because of the short distance in time that the post-modernist style continues to evoke ambivalent feelings - broad recognition and appreciation of the style has not yet occurred. The question of personal taste arises clearly in the assessment of buildings and many people describe the buildings as 'preposterous', 'ghastly', 'ugly', 'dubious', 'utopian', 'fairy tale-like', 'unharmonious', etc. The questionnaire did not distinguish between owners and other people, and maybe the owners would have described the buildings using different adjectives.

One important aspect that needs to be highlighted is that each building is someone's home, and therefore undergoing constant change. Due to the particularities of the period, some of the buildings were unfinished or completed in stages. Also, the complicated architectural language does not encourage comfort, which in turn increasingly encourages people to rebuild. The questionnaire clearly revealed energy efficiency as a potential

19 Salvador Muñoz Viñas, Contemporary Theory of Conservation (Oxford: Elsevier, 2005), 5-6. 20 Triin Reidla, Nii kole maja! Postmodernistlikud elamud ja nende väärtustamisproblemaatika. Master's thesis (Tallinn: Eesti Kunstiakadeemia, 2020).

21 Ibidem, Appendix 2 
problem, since one common feature of homes from that time is the (inefficiently) large internal capacity. For the owner upkeep is a challenge that requires well thought through solutions. This leads to a specific problem - what and at which stage in the building's history should be valued? How is it possible to 'translate' the value so that it is understandable? Transition era architecture is difficult to position within the current system of evaluation. For example, it is hard to express authenticity, the state of preservation and atmosphere because the foundations vary - commonly understood criteria with which to assess the value of the building are lacking. Comments in the questionnaire in Reidla's thesis drew attention to this, If I am completely honest, then I looked at these pictures for quite a while and... I wasn't able to make a selection. For me this is an unknown period, it is difficult to assess this architecture - there is no value system with which to approach this style. It is hard to assess it as one would baroque or historicist. At the same time it is a similar phenomenon as in previous eras. ${ }^{22}$ One criteria for evaluating has been the fame of the architect and their importance within architectural history. ${ }^{23}$ Many architects of buildings designed in the 1980s and early 1990s are still unknown today. In future research of this period, including residential architecture, it might be good to focus greater attention on the work of the most prolific architects of the era. For example, buildings in the residential suburbs of Rehe st. in Viljandi and the suburb of Ihaste in Tartu have been designed by very productive architects who designed many homes in a genuine postmodernist style, including Koit Köbas, Kalvi Voolaid, Maret Tääker, Vilmar Lill and many others whose names one does not come across in architecture history.

23. Implementing legislation for the Heritage Protection Regulation "Mälestise liikide ja muinsuskaitseala riikliku kaitse üldised kriteeriumid ning muinsuskaitsealal asuvate ehitiste väärtusklassid", Riigi Teataja, 16.05.2019, https://www.riigiteataja.ee/akt/116052019001 [accesse on 07.12 .2019$]$.

\section{RESIDENTIAL ARCHITECTURE IN HERITAGE PROTECTION AREAS}

Even though many new housing developments were being built in the 1980s-1990s, residential architecture practices also had an affect on already well-established historical urban spaces. Here we can look at two quite different situations - the historical centres of cities that were already under heritage protection and the wooden suburbs that lay just outside these. In the case of the heritage protected areas, there is primarily the question of how the heritage protection restrictions shaped the architectural appearance of the new buildings and whether the homes built at that time should be viewed as an organic and valuable part of the historical urban space or do they continue to be 'foreign bodies'.

Areas under heritage protection had relatively clear rules and as previously mentioned heritage protection regarding residential buildings also differed from the remainder of the building system. Right after the creation of heritage protection areas (Tallinn 1966, Tartu and 8 smaller towns 1973), urban planning schemes were established. The centres of cities under heritage protection were excluded from the urban planning schemes and while urban planning for the remainder of the city was compiled by the design institute Eesti Projekt, then planning for heritage protected areas was handed over to the restoration system. In the beginning, it was the appropriate department at Vabariiklik Restuareerimisvalitsus (State Restoration Administration) who dealt with these and later the Kultuurimälestiste Riiklik Projekteerimise Instituut (Cultural Monuments State Design Institute) established in $1978 .{ }^{24}$ Urban planning of the old towns was very detailed and in addition to questions about restoration, these also addressed issues of traffic, greenery and other aspects of urban planning.

Making the most of the quirks of the Soviet system (centralised rule, limitations on private ownership), they endeavoured to anticipate the future function of each building in the heritage protected areas. In

24 Riin Alatalu, Muinsuskaitse siirdeühiskonnas 1986-2002. Rahvuslikust südametunnistusest ENSV-s omaniku ahistajaks Eesti Vabariigis = Heritage in Transitional Society 1986-2002: From the Nation's Conscience in the Estonian SSR to the Harrasser of the Owner in the Republic of Estonia (Tallinn: Eesti Kunstiakadeemia, 2012), 122-126; Heino Uuetalu, "Arhitektuuripärand uurimine ja projekteerimine aastail 1978-88", Eesti Ehitusmälestised (Tallinn: Valgus, 1990), 3-9. 
the case of residential buildings, they determined how many families might live in a particular building. In Tallinn and Tartu, extensive studies were carried out block by block, which was supposed to determine whether a particular building would be suitable as a residence or for some other purpose. According to the thinking at the time, the number of inhabitants in the old towns was expected to decrease; during the post-war housing shortage, the number of people forced to live in many buildings was excessive - a situation that continued in some places until the 1980s. ${ }^{25}$ In some smaller towns; for example, Lihula and Rakvere, the opposite was already apparent in the 1980s - buildings became empty and the old towns were unpopular as places to live.

Of course, immediately after the heritage protection areas were established they started to seek ways of fitting new buildings into the old towns. Explanatory notes in the urban planning schemes of the 1980s reveal relatively uniform and general condemnation of the modernist building practices of the 1960s. In addition to the demand for more appropriate sized buildings (in the context of small towns, this meant one to three-storey buildings instead of the typical standard five-storey residential buildings), there were also attempts to fight against the standard designs by demanding one-off designs that took into consideration the specifics of each old town property and/ or to find 'old town' types suitable for the historical environment. ${ }^{26}$ The requirement of making buildings suit the historical context helped the spread of milieu-sensitive postmodernism in 1980s Estonia. Many of the most emblematic examples of architecture from that time are located in old towns. Classic examples that have been highlighted include Vilen Künnapu's flower shop (completed 1983) and Kalle Rõõmus' housing administrative building, secreted within the re-established earthen fortification (completed 1986) in Tallinn, Toomas Kivi's fish shop (1985) and Lilian Hansar's residence on Lossi st. (1988) in Kuressaare, and many others.

25 For more see: Oliver Orro, "Süstemaatiliste unistuste aeg. Vanalinnade planeeringutest Eestis 1960.-80. aastatel", Aja lugu. Muinsuskaitse ja restaureerimise ajaloost, ed. by Annel Eesti NSV-s. Linnsüdamete säilitimine totalkaitse meetodil”, Kunstiteaduslikke Uurimusi, 3-4 (18) (2019), 90-92; Rasmus Kangropool “Talline vanalinna regenereerimisest”, Eesti Ehitusmälestised (Tallinn: Valgus, 1990), 10-15.

26 Hain Toss, "Eesti ajalooliste linnade regenereerimine”, Ehitus ja Arhitektuur, 1-2 (1985), 64; Lilian Hansar, "Uued majad vanas linnas", Järelevastamine. Kaur Alttoale (Tallinn: Eest Kunstiakadeemia, 2017), 209-262.
However, it must also be noted that postmodernism continued to smoulder for a while and postmodernist buildings continued to be built in the small towns in the 1990s and even 2000s. This became increasingly anachronistic and later produced both less convincing and also quite original examples. New houses built in heritage protected areas in small towns in the 1990s, still according to the spirit of the previous decade, are now the most confusing - time will tell whether these, for many people, embarrassingly old-fashioned and even tasteless buildings, will emerge as vivid landmarks worthy of preservation.

Against the background of the postmodernist re-interpretation of historical building traditions in the 1980s and early 1990s, a fairly large number of copies were also built. Copies were made of buildings that were still standing but in bad condition, as well as buildings that had perished decades previously. Already at that time this practice caused discussion among experts, as well as direct opposition, but for various reasons it occurred quite often. One impetus was poor availability of the necessary materials for restoration; for example, it was easier to get silicate bricks than to prop up a fungus-damaged wooden building with the necessary large crossbeams, and there were problems accessing quality lime, etc. ${ }^{27}$ On many occasions copies were built of old or original Baltic (urbaltisch) type houses, preserving only the original mantel chimney in the centre of the building because the original timber construction was in poor repair, but still wishing to preserve the city's oldest residential buildings. ${ }^{28}$ One such building is in Rakvere on Pikk st. and now operates as the Rakvere Citizen's Museum. The building of copies can often be seen in places where some urban layering was disappearing and attempts were made to save it at all cost and bring it back to life, such as the local semi-vernacular baroque in Pärnu and in the resort period in Kuressaare. ${ }^{29}$ A systematic stocktake and analysis of buildings in heritage areas has once again been achieved in Estonia and one group

27 Interview with Jaan Mitt the one time head of the Saaremaa restaureerimisvalitsus (Saaremaa Restoration Administration) (2017). Oliver Orro's notes.

28 For house type and its restoration see: Oliver Orro, "Urbaltisch-houses are the Most Dignified Historic Buildings of Estonian Towns", Estonian Cultural Heritage. Preservation and Urban Planning Department, 2017), 75-82.

29 Interviews with Lilian Hansar and Rein Raie restoration architects of that time (2018). Recordings and notes in the authors' collections. 
of buildings that elicits the most questions in regard to assessment is these copies built in the 1980s to 1990s. The question of whether baroque details made in the 1980s are of equal value to those from the 1680 s, has not yet in our restoration practice produced any single comprehensive answer.

\section{THE PRESSURE FROM NEW ARCHITECTURE ON HISTORICAL RESIDENTIAL SUBURBS}

A milieu-sensitive approach regarding historical wooden suburbs has today become the norm, but during the 1990s, new building practices were based on quite different criteria. The most influential factor regarding the built landscape was certainly the changes regarding ownership. The ownership reform was one of the most important reforms of the transition period and its aim was to change society through the creation of ownership, as is typical in a market economy. The reform process began in summer 1991, with the passing of regulations that laid the foundations for ownership reform, which culminated in the late 1990s. During the reform over 420000 privatised apartments were recorded in the Property Register. A special section of the ownership reform was restitution - the return and compensation for illegal disposession - whose aim was to make good the injustice for violations against property ownership. Based on data collected in 1990, close to 6,000 houses; in other words, $50 \%$ of houses that had been nationalised in 1940 still existed. ${ }^{30} \mathrm{~A}$ large number of these houses older than 50 years were situated in the centres of towns or suburbs, and they now often fell into the hands of developers, a new type of entrepreneurship, as well as attracting the attention of heritage protection.

Competition against property developers resulted from the fact that even though there had been talk in defense of the wooden suburbs already in the 1970s, no practical steps had been taken. Unlike the protected old towns, the suburbs, dominated by wooden buildings, had for decades been under threat of demolition. During the 1960s and 70 s, when entire old suburbs were demolished, they also managed on the whole to build new buldings in their place, but in the $1980 \mathrm{~s}$, especially in the second half of the decade, demolition tended to

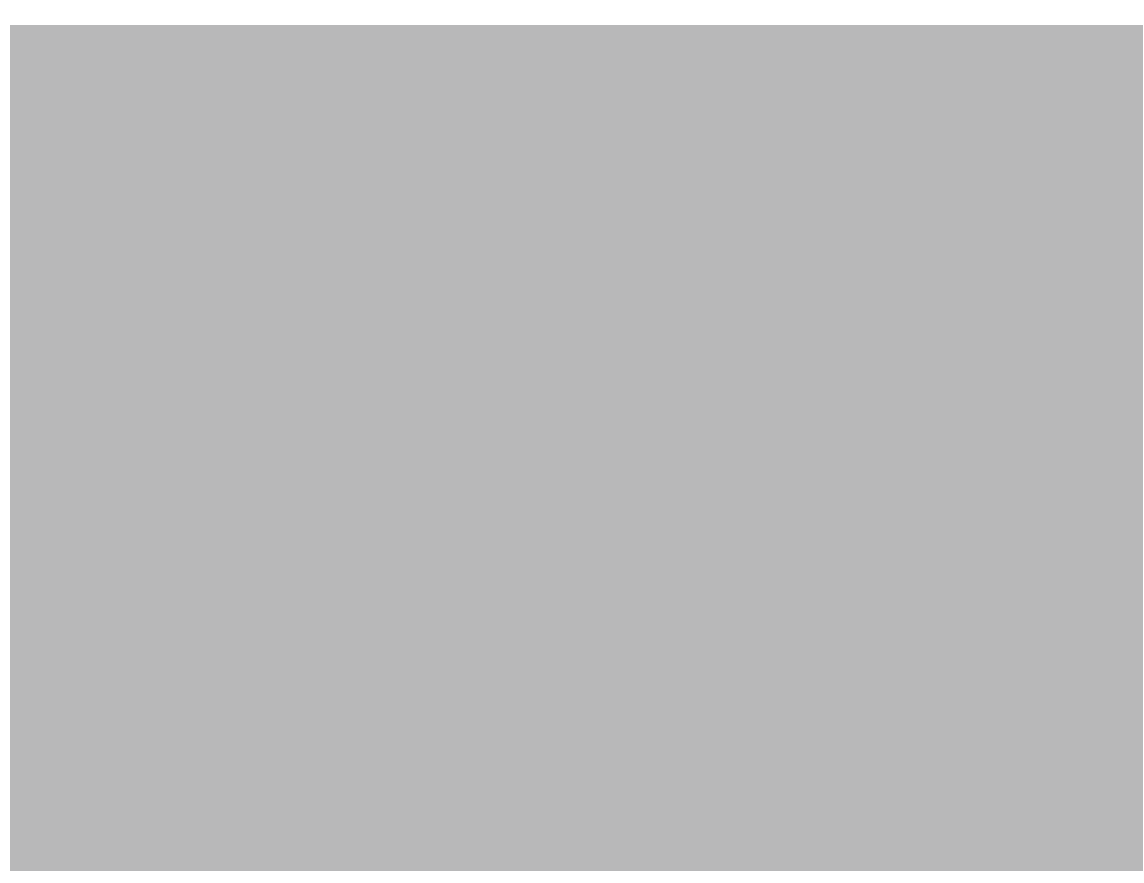

FIG. 1. ILLUSTRATION FROM THE NEWSPAPER SIRP JA VASAR, 13.02.1987.

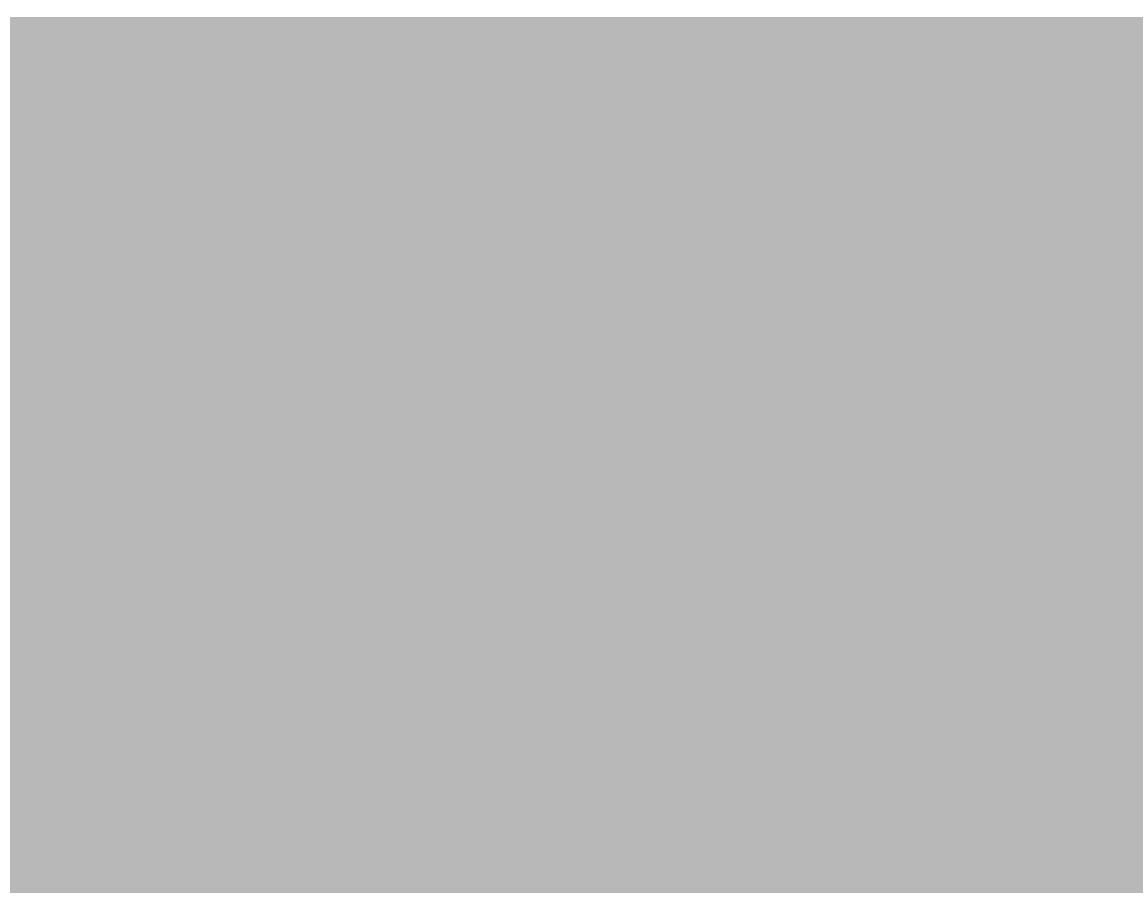

FIG. 2. ILLUSTRATION FROM THE NEWSPAPER SIRP IA VASAR, 09.10.1987. 
exceed new buildings. ${ }^{31}$ Despite many important conferences ${ }^{32}$ towards the end of the 1980s, when the Soviet mentality was coming apart at the seams and the new residential areas were held in public derision, there were still plans to demolish, for example, the Süda st. quarter and suburb of Kalamaja in Tallinn. Süda st. stood in the path of plans to extend Rävala avenue as a motorway and build a new opera house. But the issue was not only about planned new buildings but also the continuing derision of leading architects towards anything old. For example, the architect Irina Raud enthusiastically presented in the media the need to demolish the delapidated buildings in Kalamaja, Süda st. and also in the rest of Tallinn. ${ }^{33}$ In response to these plans a whole string of articles appeared in the media in defense of wooden buildings, and in 1987 the Vabariiklik Arhitektuurimälestiste Kaitse Inspektsioon (State Architectural Monuments Protection Inspection) made a proposal, on the basis of a preliminary inventory, to declare Kadriorg a heritage protection area, and the Nõmme Heakorra Selts (Nõmme Maintenance Society) proposed that 40 buildings in Nõmme be taken under protection and that a heritage protection area also be established. The city government declined to pass these proposals. ${ }^{34}$

Houses and property were returned to private ownership and in the case of almost all the buildings, plans were made to make changes, though these were not always carried out. This may have been in the form of nostaglic restoration, daring modernisation or the replacement of 'decaying architecture' with a modern building. Because many former owners or their descendents were happy with the compensation, this opened the way for a new type of enterprise - property development. The pressure to develop focused on areas close to city centres and suburbs with already established infrasture and living environments and consequently dozens of buildings that

31 Karin Hallas-Murula, "Changing Slums", Estonian Art, 2 (2002), http://arhiiv.estinst.ee/Ea/ heritage/hallas2.html [accessed 13.03.2020]; Triin Talk, "Kuhu küll kõik maja jäid", Puithoone ja muinsuskaitse, Tallinna puitarhitektuur (Tallinn: Eesti Kunstiakadeemia, 2002), 375-380, Of Contextuality", Drewno w Architeturze/Wood in Architecture, ed by Jan Kurek (Krakow: Politechnika Krakowska, 2016).

32 For example: Tallinna seminar 25-27.04.1980. Organiser Ignar Fjuk. Estonian SSR Architect's Association.

33 Ivo Laks, "Kalamaja 33 kvartalit", Sirp ja Vasar, 16. 01.1987; Irina Raud, "Linnakeskuse perspektiivarengust", Öhtuleht, 24.01.1986.

34 MKA, VAMKI/VLAKV. Correspondence about general heritage protection issues 18.01.1988-6.10.1993. were architecturally valuable to experts, but for the general public dilapidated, were demolished. Because demolition required a permit, many buildings were simply set on fire. At the turn of the century in Kadriorg the following buildings burned down - 4 Vesivärava, 2 F. J. Wiedemanni, 8 and 25 J. Poska, 3 Kadri tee and others. Even as late as 2014 this continued when 6 L. Koidula and 36 J. Poska were burned down.

While flamboyant post-modernist houses were still being built in the new suburbs on the outskirts of towns in the 1990s, the first houses being built in the predominantly wooden suburbs tended to be more like laconic, functionalist boxes. Even so, built in between the historical buildings, these new houses were still pretentious because they were generally much larger than the surrounding buildings. Examples in Kadriorg, where of all the Tallinn suburbs the most active building work took place in the 1990s, include architekt Raivo Puusepp's house at 5 J. Vilmsi st./36 Raua st. (1997), which is many times larger than the surrounding buildings. Economical box houses were built in the place of wooden buildings, for example, at $13 \mathrm{~J}$. Köleri st. (Andres Põime) and 14c L. Koidula st. (Mai Šein). Where once there were three buildings and a yard, the new apartment building at $4 \mathrm{~F}$. J. Wiedemanni st. (architect Andres Saar, 1998) now covers the entire property from edge to edge, and in terms of greenery it was justified that the neighbour's large trees would suffice. The building was first intended to be 5 storeys, but protests from the neighbours and a court order to stop construction forced the developer to forgo one storey. ${ }^{35}$ The demolition of the grand, pillared house at $12 \mathrm{~J}$. Poska st. and the plan of an oversized building also provoked protest. In response to protests by the local inhabitants the deputy head of the Säästva Arengu ja Planeerimise Amet (Sustainable Development and Planning Board) replied: There are no compulsory legal measures for the preservation of existing buildings in an area of significant milieu. The suitablity of the building in the given area is a subjective matter. ${ }^{36}$

The new building practices also motivated heritage protectors to get involved. The National Heritage Board, founded in 1993, began by looking at lists of heritage sites; this was a good opportunity to amend the list with many new buildings. The best-known example

35 Askur Alas, "Kohus peatas Kadrioru ehitusloa", Eesti Päevaleht, 10.07.2003.

36 Ibidem. 
of a valuable building that was taken under protection in order to avoid its demolition was the Linnahall (Tallinn City Hall) in 1997, and with the same aim of averting demolition and rebuilding, houses in the suburbs were also placed under protection in large numbers. In the suburbs of Tartu there are now close to 170 homes under state protection, and in Tallinn, in the suburbs of Kassisaba, UusMaailm and the Toom-Kuninga quarter alone, there are 12 in each, in Kalamaja, Pelgulinn and Süda-Tatari there are close to 20, in Nõmme close to 30 and in the suburb of Kadriorg and the Raua st. area there are a total of 57 under protection. The majority were placed under protection in the 1990s and early 2000s. In Rakvere, Võru, Viljandi and Haapsalu, where the pressure from development was less, there are no homes under protection outside the limits of the old towns.

The frenzied pressure to demolish or rebuild during the 1990s was halted with yet another option to protect historical areas at the local government level. The 2002 planning regulations made it possible to establish milieu-significant urban areas. The first attempt had already been made in Tartu much earlier, when the protected urban areas of Karlova, Tammelinn, Tähtvere and Toometaguse were established in 1995 and 1996. The 2001, Tallinn's urban plan established the first eight milieu areas on the basis of the new planning regulations and the clear principles helped ensure that new buildings respected the surrounding environment. The beginning of the new millenium saw many new apartment buildings in Kadriorg that won awards for excellent architecture and appropriateness in the surroundings; for example, 29 A. Weizenbergi st. (Alver Trummal Arhitektid); 24 L. Koidula st. $(3+1,2006)$ and 26 L. Koidula st. (Tiit Trummal, 2006). One could say the busy building work in the wooden suburbs in the 1990s in fact increased appreciation for the historical environment, since thanks to changes in society, heritage protection had to focus more attention there than they had previously. Over a couple of decades, the milieu suburbs, with both historical and new buildings, in most of the larger cities have become valuable real estate and have undergone classic gentrification processes. During the previous decade, a new trend has seen many new inhabitants, who don't own their own homes but rent, move to suburbs close to the city centres. The value of suburbs has been greatly influenced by the application of heritage protection principles.
Accordingly, the more the value of historical buildings increased, the more they were looked after and 'box architecture' in historical surroundings that once symbolised modernity and contemporanity became a term of derision. Public opinion was influenced by the fact that many contemporary buildings differentiated themselves provoactively with their surroundings. For example, 28 J. Poska st. (Alver Trummal Arhitektid) and 22 J. Poska st. (Emil Urbel, 2012). The general public preferred neo-historicist buildings, such as 13 J. Poska st. (2009), and 40 Vesivärava st. (2017, both Allan Struss). The new buildings built during the 1990s that disregarded their suroundings seem to have a long way to go before they can achieve value in their own right.

\section{CONCLUSION}

The transition period of the 1980s and 1990s is part of recent history, but what took place then and what was built is slowly step-by-step attracting the attention of heritage experts. Even though this article focused on residential architecture, it is also possible to make the first assessments about developments regarding new buildings and historical environments. Architecture of the early 1990s was heavily influenced by tendencies that began in the 1980s and is stylistically in essence a continuation of that decade. The playful and form-rich post-modernism of the 1980s was carried into the new society, as was the more spartan neofunctionalism that had become influential on the local architecture scene, and which paid homage to the local architecture of the 1930s and was by association connected with the highly desirable architecture of the free Western world.

The value judgements shaped in the midst of the cultural, legal and economic conditions of those times in regard to heritage from the past, paved the way for the high regard for residential areas today and consequently also the triumph of heritage protection principles in the fight against property development. In the 1990s, the mass demolition of old buildings, which had been typical of the end of the Soviet period and beginning of the new period of independence, came to end. Many of the empty holes in the city were not built on unti a couple of decades later and some are still empty now. However, this has made it possible for many exciting new buildings to be built that seek connection with the historical surroundings in areas that 
have been recognised as milieu-significant. It is worth noting that as a consequence of the provocative buildings that differed from what already existed being primarily built in these milieu suburbs in the first decade of re-independence, the application of rules and primarily the new attitudes held by the general public and clients, has in the 21st century paved the way for the triumph of architecture that blends in with the historical environment.

Residential architecture of the transition period, as potential heritage, is clearly problematic. The assessment of its value is made complicated by its recentness in history, as well as factors regarding specific buildings, such as the function of the home and the complexity of the opposing feelings provoked by the postmodernist style. Modern materials are also part of the arsenal of values from the transition period, and the assessment and options for preservation still need to be assessed. The relative poverty during the period before and immediately after the collapse of the Soviet Union forced many people to use cheap materials, and in the long term their preservation may prove problematic. The enthusiasm for the new materials and the ways they could be used to create innovative architecture and modern homes is a typical characteristic of the period.

Appreciation of architecture has always been subjective, dependent on knowledge and experience. Attributing value and thereby possibly recommending protection is made more difficult by the paucity of research. We encourage those who are currently taking stock of heritage protected areas and valuable milieu areas to also provide value assessments about buildings built during the last decade. The buildings from the previous couple of decades are slowly shifting from the focus of architecture criticism into the sphere of heritage protection. Quantitative material that is collected makes it possible to make more accurate conclusions.

The problematic areas highlighted in this article clearly demonstrate that it is time to start broad-based discussions about the appreciation of transition period architecture and this should not only involve heritage experts but other interested parties as well.
Ritn Alatalu, Maris Mändel, Oliver Orro, Tritn Reidla: A Controversial Heritage. Residential Architecture of the Transition Period in Estonia

KeyWords: architectural heritage; POSTMOdernism; transition; CITY PLANNING

\section{SUMMARY}

Heritage conservators are expected to be a step ahead of the general appreciation of values of the past. This article looks at residential architecture during the transition period in Estonia from the late 1980 s to the early 1990s through the eyes of heritage experts. The legacy of the period is controversial - the vanity of 1980s postmodernism is shadowed by Soviet-era energy ineffectiveness and poor building quality. The first decade of the restored Republic of Estonia reflects the intrusion of new architectural tendencies into historic urban areas. The aim of this article is not, however, to study 1990s residential architecture from the point of view of critical heritage research, nor to determine suitable methods for doing so, but rather it is an attempt to provide an initial framework based on information from architecture history and building history in regard to specific buildings and to highlight potential problems that could arise from the implementation of traditional discourse regarding heritage, and thereby create a need for alternative approaches in the discussion.

\section{CV}

Riin Alatalu, PhD (b. 1968) is an associate professor of cultural heritage and conservation at the Estonian Academy of Arts. She has a PhD in heritage conservation (Heritage in Transitional Society from Nation's Conscience in the Estonian SSR into the Harasser of the private Owner in the Republic of Estonia, 2012). Alatalu has worked for the National Heritage Board, Tallinn Culture and Heritage Department and the Estonian Ministry of Culture in supervisory 
positions with responsibility for the promotion of heritage and significant international programs. She is a member of the Board of ICOMOS International and president of ICOMOS Estonia. She is the chairperson of the Estonian Heritage Conservation Council.

Maris Mändel, $\mathrm{PhD}$ (b. 1982) is a junior research fellow in the Department of Cultural Heritage and Conservation at the Estonian Academy of Arts. Her research focuses on conservation of $20^{\text {th }}$ century built heritage. She has 15 years of practical experience in investigating historical buildings and supervising conservation work.

Oliver Orro, MA (b. 1982) is an architecture historian working for the Division of Cultural Heritage in Tallinn City Planning Department. He also lectures at the Estonian Academy of Arts. Orro has written numerous books and articles on $19^{\text {th }}$ and $20^{\text {th }}$ century historical wooden suburbs in Estonia, and on industrial and military heritage.

Triin Reidla, MA (b. 1992) works at the Estonian National Heritage Board. In 2020 she defended her master's thesis, titled Such an Ugly House! Postmodern Residential Buildings and Issues of Evaluation on a previously unexplored controversial topic. 